\title{
Rethinking suicide: From pre-Durkheim suicidology to contemporary theories
}

\author{
Hong Kong Nguyen \\ February 15, 2021
}

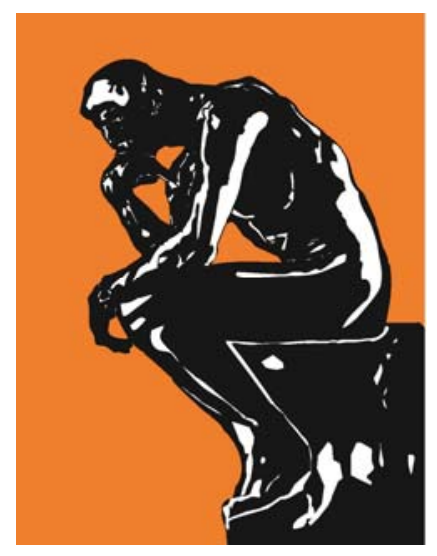

$A I S D L$

"The longing for order is at the same time a longing for death, because life is an incessant disruption of order."

(Milan Kundera, The Unbearable Lightness of Being [1])

\section{$18^{\text {th }}$-century studies}

In 1897, the French sociologist Émile Durkheim published what is to become a foundational text in sociology and social psychology, titled Le Suicide: Étude de Sociologie (trans., Suicide: A study in sociology) [2]. Little known outside mainstream academia is how the scientific study of suicide-suicidology — had taken off in the preceding centuries $[3,4]$.

Some earlier hallmark works include the German moral statistician Adolf Heinrich Gotthilf Wagner's 1864 masterwork titled Die Gesetzmaessigkeit in den Scheinbar Willkuerlichen Menschlichen Handlungen vom Standpunkte der Statistik (trans., The Lawful Regularity of Apparently Voluntary Human Actions Seen from the Standpoint of Statistics) [5], the 1887 publication of Suicide: An Essay on Comparative Moral Statistics 
by the Italian psychical researcher Enrico Morselli [6], and the 1892 comprehensive reviews of suicide research by the English physician Daniel Hack Tuke [7].

These early studies share the idea that grasping the statistics behind suicide could improve our understanding of the act itself. In his essay, Morselli posits suicide as a voluntary human act shrouded in "metaphysical obscurity," all the while acknowledging suicide as inevitable during society's natural course of development (p. 1). His argument is grounded on the idea that only statistics—which he calls "an exact science" (p. 10)_ could provide us with true knowledge about social phenomena, such as suicide. Similar to Wagner's earlier work, what Morselli lays out is the statistics of suicide, through which patterns of suicidal acts are observed, questions asked, and inferences drawn. For instance, where can irregularities in statistics on suicide be found? Is temperate climate a risk factor for suicide when regions with certain climatic conditions coincidentally mark a relatively higher rate of suicide? This line of the question-concerning the influence of climate and seasonal temperature-is later explored, questioned, and eventually rejected in Durkheim's work.

According to Durkheim, psychosocial factors, rather than geographical and climatic conditions, play a more important role in determining suicidal attitudes and behaviors. He famously lists four types of suicide, namely (i) egoistic suicide, (ii) altruistic suicide, (iii) anomic suicide, and (iv) fatalistic suicide, with the first two related to social integration issues (e.g., social connectedness and interconnectedness) and the last two related to social regulation issues (e.g., anarchy, democracy, dictatorship, etc.). An extremely high or extremely low degree of social regulations may lead to suicide. His line of reasoning and approach, visualized in Figure 1, has become the epicenter of suicidology in the post-Durkheimian period.

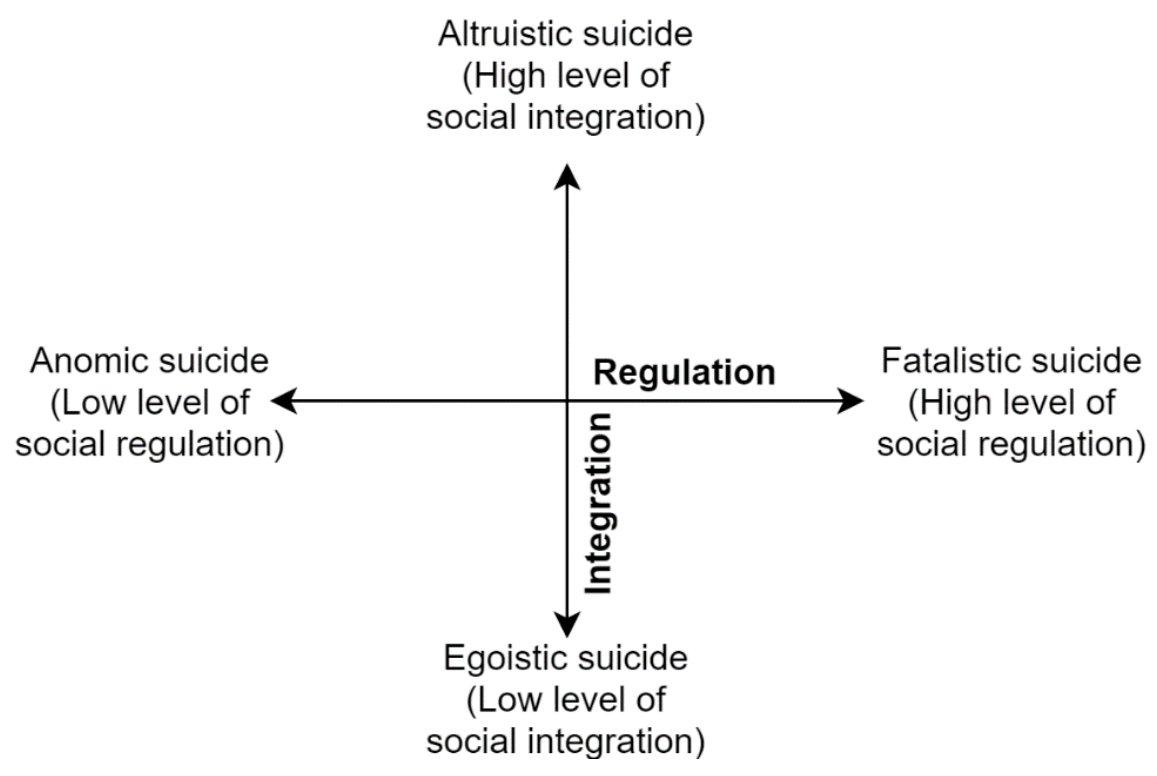

Figure 1. Emile Durkheim's four types of suicide 


\section{Contemporary theories}

Fast forward to the $20^{\text {th }}$ and $21^{\text {st }}$ centuries, while scholars have developed sophisticated methods and models to study suicide and related suicidal factors, there is, in fact, little agreement on how suicidal thoughts arise.

Not only has suicide remained a major global health issue, but it also continues to elude human understanding to this day. In his extensive studies on the theories of suicide, John Gunn and David Lester divide them into two major categories: the psychological theories and the sociological and economic theories [8].

Integral to these theories are elements of: a sense of belongingness or social connectedness, perceived burdensomeness (the needs of a society supersede those of an individual), prolonged psychological pain, a sense of defeat, and entrapment.

Table 1 recaps the main content of some prominent contemporary theories of suicide.

\begin{tabular}{|c|c|c|c|c|}
\hline Theory & Abbrv. & Origin & Authors & Keynotes \\
\hline $\begin{array}{l}\text { Economic } \\
\text { theory of } \\
\text { suicide }\end{array}$ & ETS & 1974 & $\begin{array}{l}\text { Daniel S. } \\
\text { Hamermesh, } \\
\text { and Neal M. } \\
\text { Soss [9] }\end{array}$ & $\begin{array}{l}\text { Economic factors such as } \\
\text { unemployment can be a predictor } \\
\text { for suicide; }\end{array}$ \\
\hline $\begin{array}{l}\text { Network } \\
\text { theory of } \\
\text { suicide }\end{array}$ & NTS & 1989 & $\begin{array}{l}\text { Bernice A. } \\
\text { Pescosolido, } \\
\text { and Sharon } \\
\text { Georgianna } \\
{[10]}\end{array}$ & $\begin{array}{l}\text { Durkheimian; the continued } \\
\text { relevance of identifying religion's } \\
\text { effects on suicide rates; a network } \\
\text { theory focusing on the relationship } \\
\text { between social structures/relations } \\
\text { and individuals' attitudes, beliefs, } \\
\text { and behaviors. }\end{array}$ \\
\hline $\begin{array}{l}\text { Interpersonal } \\
\text { Theory of } \\
\text { Suicide }\end{array}$ & IPTS & 2005 & $\begin{array}{l}\text { Thomas } \\
\text { Joiner [11] }\end{array}$ & $\begin{array}{l}\text { Suicide is an act resulted from a } \\
\text { combination of the desire to die } \\
\text { and the capability to die; }\end{array}$ \\
\hline $\begin{array}{l}\text { Fluid } \\
\text { Vulnerability } \\
\text { Theory }\end{array}$ & FVT & 2006 & $\begin{array}{l}\text { Rudd David } \\
\text { [12] }\end{array}$ & $\begin{array}{l}\text { Integration of the cognitive and } \\
\text { affective systems with motivational } \\
\text { and behavioral systems; }\end{array}$ \\
\hline $\begin{array}{l}\text { Integrated } \\
\text { Motivational } \\
\text {-Volitional } \\
\text { Model }\end{array}$ & IMV & 2011 & $\begin{array}{l}\text { Rory } \\
\text { O'Connor } \\
{[13]}\end{array}$ & $\begin{array}{l}\text { A tripartite framework of biology, } \\
\text { psychology, and sociology that } \\
\text { takes into account a sense of } \\
\text { defeat and humiliation; }\end{array}$ \\
\hline $\begin{array}{l}\text { Three-step } \\
\text { Theory }\end{array}$ & 3ST & 2015 & $\begin{array}{l}\text { David } \\
\text { Klonsky and } \\
\text { Alexis May } \\
{[14]}\end{array}$ & $\begin{array}{l}\text { (i) suicidal thoughts arise from } \\
\text { pain combined with hopelessness, } \\
\text { (ii) suicidal ideation in those } \\
\text { suffering from pain and }\end{array}$ \\
\hline
\end{tabular}


hopelessness may escalate in the absence of social connectedness, and (iii) attempted suicide is the result of a combination of dispositional, acquired, and practical contributors to the capacity for suicide.

\section{Conclusion: A new proposal}

It is fascinating that the rich literature on suicide has yielded no satisfactory answer to the progression from suicidal ideation to action. In reviewing the extant research on suicide, one may note that there is a dearth of studies on suicidal thought processing. How do self-destructive thoughts arise and persist inside an individual's mind? What are the underlying mechanisms of such an ideation process?

Our research suggests that a multifiltering information system and mechanism, particularly that of the mindsponge model $[15,16]$, can provide the much-needed explanation. Suicide, when viewed through the perspective of information processing, becomes one among a million other pieces of information constantly being introduced to and either absorbed or rejected by the mind. Here, just as how the $18^{\text {th }}$-century scholars of suicide have emphasized the use of statistics, we also suggest applying Bayesian statistics to improve our understanding of suicidal ideation [17-19].

The Bayesian information update process is appropriate for analyzing the way our minds receive information-whether it be values, beliefs, or attitudes-because it takes into account the uncertainties as well as the inflows of new information that may require an internal updating.

This approach is advantageous for it builds on and integrates existing theories of suicide. A mind susceptible to suicidal thoughts and behavior is one that may suffer from one or a combination of various factors, including but not limited to low social connectedness, high perceived burdensomeness, a high sense of defeat and humiliation, and the acquired capability for suicide.

The implications are clear; the complexity of suicide calls for an integrated approach, one that draws on prominent insights and theories as well as utilizes a robust statistical method.

\section{References}

1. Kundera, M. The unbearable lightness of being; Faber \& Faber: 2020.

2. Durkheim, E. Le suicide: étude de sociologie; F. Alcan: 1897. 
3. Goldney, R.D.; Schioldann, J.A. Pre-Durkheim suicidology. Crisis 2000, 21, 181 186, doi:10.1027/0227-5910.21.4.181.

4. Goldney, R.D.; Schioldann, J.A.; Dunn, K.I. Suicide research before Durkheim. Health History 2008, 10, 73-93.

5. Wagner, A.H.G. Die Gesetzmaessigkeit in den Scheinbar Willkuerlichen Menschlichen Handlungen vom Standpunkte der Statistik; Boyes \& Geisler: 1864; Vol. 1.

6. Morselli, E.A. Suicide: An essay on comparative moral statistics; CK Paul \& Company: 1883; Vol. 36.

7. Tuke, D.H. A dictionary of psychological medicine: Giving the definition, etymology and synonyms of the terms used in medical psychology with the symptoms, treatment, and pathology of insanity and the law of lunacy in Great Britain and Ireland; Blakiston: 1892; Vol. 2.

8. Gunn, J.F.; Lester, D. Theories of suicide: Past, present and future; Charles C Thomas Publisher: 2015.

9. Hamermesh, D.S.; Soss, N.M. An economic theory of suicide. Journal of Political Economy 1974, 82, 83-98.

10. Pescosolido, B.A.; Georgianna, S. Durkheim, suicide, and religion: Toward a network theory of suicide. American sociological review 1989, 33-48.

11. Joiner, T. Why people die by suicide; Harvard University Press: Cambridge, MA, 2005.

12. Rudd, M.D. Fluid Vulnerability Theory: A Cognitive Approach to Understanding the Process of Acute and Chronic Suicide Risk. In Cognition and suicide: Theory, research, and therapy., American Psychological Association: Washington, DC, US, 2006; 10.1037/11377-016pp. 355-368.

13. O'Connor, R.C. Towards an integrated motivational-volitional model of suicidal behaviour. International handbook of suicide prevention: Research, policy and practice 2011, 1, 181-198.

14. Klonsky, E.D.; May, A.M. The Three-Step Theory (3ST): A New Theory of Suicide Rooted in the "Ideation-to-Action" Framework. International Journal of Cognitive Therapy 2015, 8, 114-129, doi:10.1521/ijct.2015.8.2.114.

15. Vuong, Q.H. Global mindset as the integration of emerging socio-cultural values through mindsponge processes: A transition economy perspective. In Global Mindsets, Kuada, J., Ed. Routledge: 2016; pp. 123-140.

16. Vuong, Q.H.; Napier, N.K. Acculturation and global mindsponge: an emerging market perspective. International Journal of Intercultural Relations 2015, 49, 354367.

17. Vuong, Q.-H.; Ho, M.-T.; La, V.-P. 'Stargazing' and p-hacking behaviours in social sciences: some insights from a developing country. European Science Editing 2019, 45, 54-55. 
18. Vuong, Q.-H.; La, V.-P.; Nguyen, M.-H.; Ho, M.-T.; Tran, T.; Ho, M.-T. Bayesian analysis for social data: A step-by-step protocol and interpretation. Methods $X$ 2020, 7, 100924, doi:10.1016/j.mex.2020.100924.

19. La, V.-P.; Vuong, Q.-H. bayesvl: Visually Learning the Graphical Structure of Bayesian Networks and Performing MCMC with 'Stan'. Available online:

https://cran.r-project.org/web/packages/bayesvl/index.html 